\title{
Various Shallot Seed Treatments with Trichoderma to Increase Growth and Yield on Sandy Coastal
}

\author{
Stefany Darsan ${ }^{1 *}$, Endang Sulistyaningsih ${ }^{1}$, Arif Wibowo ${ }^{2}$ \\ ${ }^{1}$ Department of Agronomy, Faculty of Agriculture, Universitas Gadjah Mada \\ Jln. Flora no. 1, Bulaksumur, Sleman, Yogyakarta 5528, Indonesia \\ ${ }^{2}$ Department of Plant Protection, Faculty of Agriculture, Universitas Gadjah Mada \\ Jln. Flora no. 1, Bulaksumur, Sleman, Yogyakarta 5528, Indonesia \\ *Corresponding email: stefanydarsan721@yahoo.co.id
}

Received: $9^{\text {th }}$ August 2016 ; Revised: $16^{\text {th }}$ November 2016 ; Accepted: $18^{\text {th }}$ August 2017

\begin{abstract}
Sandy coastal area is a poor land, with minimal nutrients and low ability to store water and nutrition. Therefore, plant is difficult to grow well, consequently the treatments for improving sandy coastal is required before planting to support their growth. Application of Trichoderma as a plant-growth promoting and controlling pathogens had been known. Shallot seed treatment by Trichoderma agents was intended to improve and support plant growth and yield in the sandy coastal land. The aim of experiment was to determine the most effective treatment to improve growth and yield of shallot on sandy coastal land. The experiment had been carried out in Yogyakarta during August - November 2015. The factorial treatments of cultivar and Trichoderma applications were arranged in Completely Randomized Design with three replications. The shallot cultivars consisted of Tiron, Crok, and Biru, while Trichoderma application consisted of control (no treatment), sprayed with Trichoderma, soaked in Trichoderma, matricontioning media i.e. rice husk charcoal and brick in combination with Trichoderma. The collected data related to plant growth and yield. The result showed that seed treatment methods with Trichoderma increased the plant height, the leaf area index, extensive root, net assimilation rate (NAR), plant growth rate (PGR), Nitrate Reductase Activities (NRA), total chlorophyll, and fresh bulb weight. The best technical treatment for cultivar Tiron was soaked with Trichoderma, and Crok was sprayed with Trichoderma, while Biru cultivar was using brick in combination with Trichoderma.
\end{abstract}

Keywords: Sandy Costal, Shallot, Trichoderma

\section{INTRODUCTION}

Shallot (Allium Cepa L. Aggregatum group) was one of the important vegetable crops with high value in the tropical regions. Because of its pungency for food, spice, and seasoning, shallot was often used as a traditional medicine for various ailments and a source of biofar (Sulistyaningsihet et al., 2002; Lanzotti, 2006; Merhi et al., 2008). Therefore, shallot's demands always increase. Production of shallot bulbs with leaves in D.I. Yogyakarta in 2013 was 10.68 tonnes per hectare, while in 2014 the production was 9.60 tons per hectare decreased. The overall decline in production was due to lower harvested area in each district (Anonymous, 2015) and limited fertile land for shallot cultivation. Cultivation of shallot in sandy coastal land could be an alternative for shallot development (Rajiman, 2014). Sandy coastal was a poor land, it is containing low clay, dust had minimal nutrients so the ability to store water was low (Rajiman et al., 2008).

Sowing the high quality of shallot seed was necessary for commercial production. The low seed quality of shallot would result in low seed emergence and the young plants would susceptible to abiotic and biotic pressures, and in turn would result in decreased yield (Ilyas, 2006; Sutariati et al., 2014). Treatments to improve quality were very important to produce healthy seeds before planting so that they can support their growth and development in sandy coastal conditions and high produtivity. Seed treatment such as seed soaked, sprayed, and congenital media combined with microorganism to protect seed which was called biomatriconditioning (Ilyas, 2006; Sutariyati et al., 2013) was usually applied to overcome seed problems.

Trichoderma is a genus of fungi that included in 
anamorphic fungi isolated from soil or organic matter (Monte, 2001). This fungi group was known effective and safe, as the fungal antagonist reduces multiplication pathogens, provide indirect effect on plant health (such as growth promoters of plants and improve plants fertility), produce enzymes that could degrade fungal pathogens cell wall, produce antibiotics that could kill pathogens, growth promoting and development of plants, as well as plant resistance inducers (Harman, 2000). Therefore, Trichoderma was used as seed treatments with various methods. The objective of this study was to obtain the best method for application of Trichoderma on shallot seed for production in sand coastal land.

\section{MATERIALS AND METHODS}

This study had been carried out during August November 2015 at Samas Beach, Bantul subdistrict, Yogyakarta and Laboratory of Crop Science, Faculty of Agriculture, Universitas Gadjah Mada, Yogyakarta. The materials used were three shallot cultivars, Trichoderma, rice husk charcoal, and brick.

The factorial treatments of cultivar and Trichoderma applications were arranged in Completely Randomized Design with three replications. The shallot cultivars consisted of Tiron, Crok, and Biru, while Trichoderma application consisted of control (no treatment), sprayed with Trichoderma, soaked in Trichoderma, matricontioning media i.e. rice husk charcoal and brick in combination with Trichoderma. Thus there were 15 combinations of treatments with three replications with the total of 45 experimental units.

\section{Preparation of Trichoderma Application}

The application of Trichoderma as follow: 1) The sprayed Trichoderma: the suspension of Trichoderma 25 g. $\mathrm{L}^{-1}$ was sprayed to the plants since 0 days old using a handsprayer. The application interval was seven days; 2) Soaked Trichoderma: the seeds were soaked in the solution of (suspended) 25 g. $\mathrm{L}^{-1}$ Trichoderma for 10 hours then exposed in the room temperature for 12 hours; 3) Biomatriconditioning method. This method needed matriconditioning (softening the rice husk charcoal or brick, then sift through a sieve of $0.5 \mathrm{~mm}$ passes then dried under direct sunlight). Biomatriconditioning: $1 \mathrm{ml}$ suspension of Trichoderma $25 \mathrm{~g} . \mathrm{L}^{-1}$ was mixed with powder of matriconditioning $1.5 \mathrm{gr}$ and the seed ( 2 gr seed mix: 1.5 gr media: $1 \mathrm{ml}$ water). Shallot bulbs treated with biomatriconditioning were placed at room temperature for 12 hours then the shallot bulbs were planted directly.

\section{Plant Growth Analysis}

Plant height observed by using a measuring ruler at the base of the root to the growing point. Leaf Area Index (LAI), was a leaf area (A) on every unit of soil area $(\mathrm{P})$ that could be expressed in a mathematical formula as follows: $\mathrm{LAI}=\mathrm{A} / \mathrm{P}$. Root area was measured by using a leaf area meter. Nitrate Reductase Activities (NRA) $\left(\mathrm{mol} \mathrm{NO}_{2}^{-} \cdot \mathrm{g}^{-1} \cdot \mathrm{h}^{-1}\right)$ using the method used by Bates et al. (1973). The levels of NRA was declared in the amount of $\mathrm{NO}_{2}$ micromoles. $\mathrm{g}^{-1} \cdot \mathrm{h}^{-1}$ by the equation:

$$
N R A=\frac{A S}{A_{0}} \times \frac{1000}{\mathrm{~B}} \times \frac{1}{T} \times \frac{500}{1000}
$$

whereas: $\mathrm{AS}=$ the value of absorbance of the solution, $\mathrm{A}_{0}=$ absorbance value of the standard $(0.0106$ or $0.0142), \mathrm{B}=$ fresh weight of leaf samples, $\mathrm{T}=$ incubation time.

Net Assimilation Rate (NAR) was the rate of dry weight increased at a particular time $(\mathrm{T})$ per unit of soil area (L) that could be expressed in a mathematical formula as follows:

$$
\mathrm{NAR}=\frac{W_{2}-W_{1}}{T_{2}-T_{1}} x \frac{\ln L a_{2}-\ln L a_{1}}{L a_{2}-L a_{1}}
$$

where: $\mathrm{W}_{1}=$ total plant dry weight at $1^{\text {st }}$ observation, $\mathrm{W}_{2}=$ total plant dry weight at $2^{\text {nd }}$ observation, $\mathrm{T}_{1}=$ observation $1^{\text {st }}$ day, $\mathrm{T}_{2}=$ observation $2^{\text {nd }}$ day, $\mathrm{La}_{1}=$ leaf area at the $1^{\text {st }}$ observation, $\mathrm{La}_{2}=$ leaf area at the $2^{\text {nd }}$ observation.

Plant Growth Rate (PGR) was defined as every increased dry weight per every unit of soil area (W) that can be expressed in a mathematical formula as follows:

$$
\mathrm{PGR}=\frac{\mathrm{W}_{2}-\mathrm{W}_{1}}{\mathrm{~T}_{2}-\mathrm{T}_{1}}
$$

where: $\mathrm{W}_{1}=$ total plant dry weight at the $1^{\mathrm{st}}$ observation, $\mathrm{W}_{2}=$ total plant dry weight at the $2^{\text {nd }}$ observation, $\mathrm{T}_{1}$ $=$ observation $1^{\text {st }}$ day, $\mathrm{T}_{2}=$ observation $2^{\text {nd }}$ day. The total chlorophyll content was calculate by using a formula $=0.0202 \times \mathrm{A} 645+0.00802 \times \mathrm{A} 663 ;$ where:A645 is the absorbance at a wavelength of $645 \mathrm{~nm}, \mathrm{~A} 663$ is the absorbance at a wavelength of $663 \mathrm{~nm}$. Bulb fresh weight.Bulb fresh weight measurements at eight weeks old after the plants were weighted by using an analytical balance.

Data were analyzed by ANOVA with $\alpha=0.05$ using SAS. If there were significant differences, the analysis was continued with Duncan's Multiple Range Test (DMRT) at $\alpha=0.05$.

\section{RESULT AND DISCUSSION}

Seed treatment could continue to increase the quality of yield (Ilyas, 2006; Sutariati et al., 2014). 
Tiron

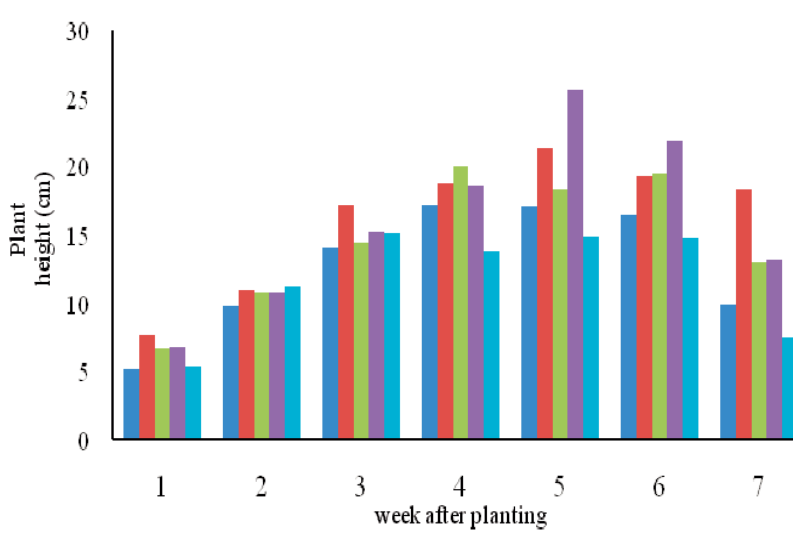

Crok

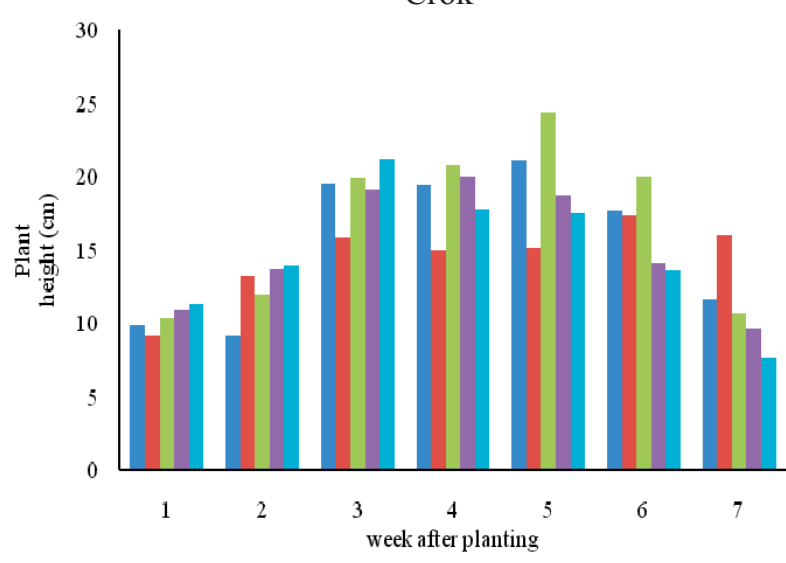

Biru

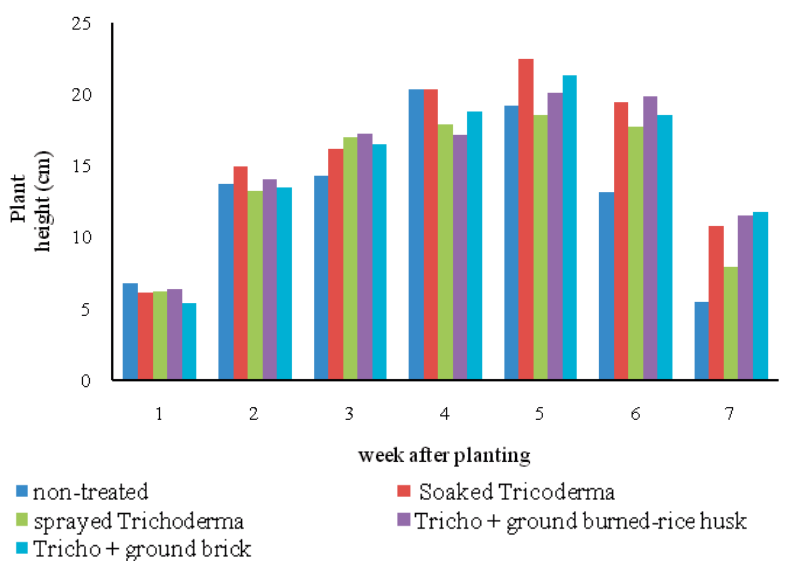

Figure 1. Effect of various seed treatment methods with Trichodermato plantheight onTiron, Crok, and $\mathrm{C}=\mathrm{Biru}$

Efforts to develop treatment techniques to protect seeds from disease and promote plant growth to maximize their yield qualities was done. The treatments used were soaking, spraying and matriconditioning with Trichoderma in order to protect seeds from pathogenic agents and to increase growth.

Compared with the non-treated, treatments of seed had no significant effect on improving shallot, either Trichoderma treatmentor cultivar types (Figure 1). Compared with non-treated, Trichoderma treatments increased plant height in early growth to late growth, except in Trichoderma integrated with brick treatment at four weeks after planting for Tiron cultivar. Compared with non-treated, Trichoderma treatments increased plant height in early growth, at one to three weeks after planting. At four to five weeks, the growth decreased because of the attack of Spodoptera, especially in Crok cultivar soaked with Trichoderma. Compared with non-treated, Trichoderma treatments did not increase plant height at early growth, but at 3 weeks after planting, plant height began to increase. At four weeks, plants were attacked by Spodoptera pest. In the weeks subsequent to plants treated with Trichoderma, significantly effect was shown on plant height improvement.

There was no interaction between cultivars and various Trichoderma treatment on leaf area index (LAI) (Table 1). There was no significantly different LAI between cultivars. Compared with the non-treated treatment, Trichoderma treatments were more effective on increasing LAI. LAI of plant treated by Trichoderma + brick treatment was higher compared with other Trichoderma treatments. The lowest LAI occured in the plant grown from seeds soaked Trichoderma treatment.

Based on the root area measurement, there was an interaction between cultivars and various Trichoderma treatment in enhancing root area (Table 2). Tiron cultivar soaked in Trichoderma produced the highest root area compared with other Trichoderma treatments. The lowest root area was found on Crok cultivar soaked in Trichoderma.

Based on net assimilation rate (NAR), plant growth rate (PGR), chlorophyll total, and Nitrate Reductase Activity (NRA) measurement, there was no interaction between cultivars and various Trichoderma application methods (Table 3). Cultivar treatments had no significant effect in increasing ANR, NAR, 
Table 1. Leaf Area Index (LAI) Plant Shallot at 8 weeks after planting (WAP)

\begin{tabular}{|c|c|c|c|c|c|c|}
\hline \multirow[b]{2}{*}{ Cultivar } & \multicolumn{5}{|c|}{ Trichoderma Treatment } & \multirow[b]{2}{*}{ Average } \\
\hline & Non-treated & $\begin{array}{l}\text { Soaked } \\
\text { Tricho }\end{array}$ & $\begin{array}{l}\text { Sprayed } \\
\text { Tricho }\end{array}$ & $\begin{array}{c}\text { Tricho+rice } \\
\text { husk charcoal }\end{array}$ & Tricho+brick & \\
\hline Tiron & 38.67 & 100.83 & 52.67 & 86.67 & 52.67 & $66.30 \mathrm{a}$ \\
\hline Crok & 64.00 & 65.33 & 81.33 & 51.33 & 34.67 & $59.33 \mathrm{a}$ \\
\hline Biru & 40.83 & 60.00 & 40.67 & 70.67 & 42.50 & $50.93 \mathrm{a}$ \\
\hline Average & $47.83 \mathrm{ab}$ & $75.39 \mathrm{a}$ & $58.22 \mathrm{ab}$ & $69.56 \mathrm{ab}$ & $43.28 \mathrm{~b}$ & $(-)$ \\
\hline $\mathrm{CV}$ & \multicolumn{6}{|c|}{23.64} \\
\hline
\end{tabular}

Table 2. Root area $\left(\mathrm{cm}^{2}\right)$ of shallot at 8 weeks after planting (WAP).

\begin{tabular}{|c|c|c|c|c|c|c|}
\hline \multirow[b]{2}{*}{ Cultivar } & \multicolumn{5}{|c|}{ Trichoderma Treatment } & \multirow[b]{2}{*}{ Average } \\
\hline & Non-treated & $\begin{array}{l}\text { Soaked } \\
\text { Tricho }\end{array}$ & $\begin{array}{c}\text { Sprayed } \\
\text { Tricho }\end{array}$ & $\begin{array}{c}\text { Tricho+rice } \\
\text { husk charcoal }\end{array}$ & Tricho+brick & \\
\hline Tiron & $11.41 \mathrm{cde}$ & $31.09 \mathrm{a}$ & $17.03 \mathrm{abcd}$ & $18.04 \mathrm{abc}$ & $13.05 \mathrm{cde}$ & 18.12 \\
\hline Crok & $13.41 \mathrm{cde}$ & $6.67 \mathrm{e}$ & 14.64 bcde & 13.44 cde & $7.88 \mathrm{de}$ & 11.21 \\
\hline Biru & 15.76 bcde & $16.98 \mathrm{abcd}$ & $19.70 \mathrm{abc}$ & $17.30 \mathrm{abcd}$ & $27.01 \mathrm{ab}$ & 19.35 \\
\hline Average & 13.53 & 18.25 & 17.12 & 16.26 & 15.98 & $(+)$ \\
\hline$\overline{\mathrm{CV}}$ & \multicolumn{6}{|c|}{17.17} \\
\hline
\end{tabular}

and PGR at three to five and five to eight weeks after planting. Cultivar treatments were significant on improving total chlorophyll content. An increase in total chlorophyll content was observed in Biru cultivar.

Compared with non-treated, Trichoderma treatments did not significantly improve NAR at three to five and five to eight weeks after planting. Trichoderma treatments were effective in improving PGR at three to five weeks after planting. The effect of treated seed was increase significantly different from the non-treated. An increase of PGR was observed on plants treated with sprayed Trichoderma. But at five to eight weeks after planting, the increasing was not significantly different compared with non treated. As an increase of total chlorophyll and ANR were observed at Trichoderma soaked treatment.

Based on the bulb fresh weight, there was interaction found between cultivars and various Trichoderma treatment in increasing fresh bulb weight (Table 4). Tiron cultivar soaked in Trichoderma showed an increase in root area compared with other Trichoderma treatment. The lowest increasing of root area was found in Crok cultivar soaked in Trichoderma.

\section{Discussion}

The results of experiment showed that various method using Trichoderma were significantly able to improve growth and yield in shallot through height plant, LAI, root area, PGR, total chlorophyll, and NRA compared with control. The results were in accordance with previous studies. As reported by Shoresh et al.(2010), the used of Trichoderma could protect plant, increase growth, help nutrient absorption, fertilizer use efficiency, and stimulation of plant defenses against biotic and abiotic damage (Shoresh et al., 2010).

Observation on growth and yield showed that there were differences in response of each cultivar with Trichoderma treatment methods. Soaking in Trichoderma was more responsive from Tiron cultivar. Tiron cultivar had a small size and lower water content of $81.25 \%$, and Tiron seeds were more resistant to high humidity. Trichoderma treatment which was applied through sprayed was more suitable for Crok cultivar. Crok had a fairly large seed size and higher water content of $86.23 \%$. The high water content was not suitable. Meanwhile, Biru cultivar was more suitable with Trichoderma brick-integrated treatment. Brick could maintain longer presence of Trichoderma at the seed. The use of solid materials caused a higher water holding capacity and better ability in maintaining microorganisms (Sutariati et al., 2013). The solid medium humidified with Trichoderma could improve the viability and vigor. Moisturization 
Table 3. Net assimilation rate (NAR), Plant Growth Rate (PGR) (kg/m2/ week) at 3-5 and 5-8 Weeks of age After planting, Nitrate Reductation activity (NRA) and Chlorophyll Total 5 Weeks After Planting.

\begin{tabular}{lcccccc}
\hline \multirow{2}{*}{ Cultivar } & \multicolumn{2}{c}{ NAR } & \multicolumn{2}{c}{ PGR } & Chlorophyll & \multirow{2}{*}{ ANR } \\
\cline { 2 - 6 } & $3-5$ & $5-8$ & $3-5$ & $5-8$ & Total & \\
\hline Tiron & $0.052 \mathrm{a}$ & $-0.012 \mathrm{a}$ & $0.4438 \mathrm{a}$ & $0.0063 \mathrm{a}$ & $0.18 \mathrm{~b}$ & $1.41 \mathrm{a}$ \\
Crok & $0.004 \mathrm{a}$ & $0.008 \mathrm{a}$ & $0.2532 \mathrm{a}$ & $0.0063 \mathrm{a}$ & $0.16 \mathrm{~b}$ & $1.34 \mathrm{a}$ \\
Biru & $0.005 \mathrm{a}$ & $0.013 \mathrm{a}$ & $0.2451 \mathrm{a}$ & $0.0446 \mathrm{a}$ & $0.29 \mathrm{a}$ & $1.54 \mathrm{a}$ \\
\hline Trichoderma & & & & & & \\
\hline Tricho Soaked & $0.023 \mathrm{a}$ & $-0.003 \mathrm{a}$ & $0.3103 \mathrm{ab}$ & $0.01348 \mathrm{a}$ & $0.26 \mathrm{a}$ & $1.68 \mathrm{a}$ \\
Sprayed Tricho & $0.035 \mathrm{a}$ & $0.004 \mathrm{a}$ & $0.5592 \mathrm{a}$ & $0.00642 \mathrm{a}$ & $0.21 \mathrm{~b}$ & $1.37 \mathrm{~b}$ \\
Tricho+Rice husk charcoal & $0.031 \mathrm{a}$ & $0.012 \mathrm{a}$ & $0.3062 \mathrm{ab}$ & $0.04422 \mathrm{a}$ & $0.24 \mathrm{a}$ & $1.52 \mathrm{ab}$ \\
Tricho+brick & $0.021 \mathrm{a}$ & $0.005 \mathrm{a}$ & $0.1419 \mathrm{ab}$ & $0.03038 \mathrm{a}$ & $0.21 \mathrm{~b}$ & $1.35 \mathrm{~b}$ \\
Non treated & $0.006 \mathrm{a}$ & $-0.004 \mathrm{a}$ & $0.2527 \mathrm{~b}$ & $0.00105 \mathrm{a}$ & $0.15 \mathrm{~b}$ & $1.25 \mathrm{~b}$ \\
\hline CV & 7.33 & 3.53 & 16.61 & 7.51 & 29.04 & 18.49 \\
\hline Interaction & $(-)$ & $(-)$ & $(-)$ & $(-)$ & $(-)$ & $(-)$ \\
\hline
\end{tabular}

Remarks: The numbers in the columns followed by the same letter werenot significantly different according to Duncan Multiple with $\alpha=5 \%$; (-): No interaction was found between factors tested; Data was transformed with $\log \mathrm{x}$.

Table 4. Bulbs Fresh weight at 8 Weeks After Planting.

\begin{tabular}{|c|c|c|c|c|c|c|}
\hline \multirow[b]{2}{*}{ Cultivar } & \multicolumn{5}{|c|}{ Trichoderma Treatment } & \multirow[b]{2}{*}{ Average } \\
\hline & Non-treated & $\begin{array}{l}\text { Soaked } \\
\text { Tricho }\end{array}$ & $\begin{array}{l}\text { Sprayed } \\
\text { Tricho }\end{array}$ & $\begin{array}{c}\text { Tricho+rice } \\
\text { husk charcoal }\end{array}$ & Tricho+brick & \\
\hline Tiron & $4.36 \mathrm{def}$ & $13.83 \mathrm{a}$ & 5.92 bcde & $12.18 \mathrm{abc}$ & $6.26 \mathrm{abcd}$ & 8.51 \\
\hline Crok & 5.30 cdef & $1.27 \mathrm{f}$ & $7.42 \mathrm{abcd}$ & $7.06 \mathrm{abcd}$ & 1.79 ef & 4.57 \\
\hline Biru & $5.54 \mathrm{bcd}$ & $9.29 \mathrm{abcd}$ & $10.07 \mathrm{abcd}$ & $9.90 \mathrm{abcd}$ & $12.63 \mathrm{ab}$ & 9.48 \\
\hline Average & 5.07 & 8.13 & 7.80 & 9.71 & 6.89 & $(+)$ \\
\hline$\overline{\mathrm{CV}}$ & \multicolumn{6}{|c|}{23.21} \\
\hline
\end{tabular}

was done to facilitate the formation of seeds (Elias, 2006).

Response of plant growth caused by Trichoderma depends on their ability to survive and thrive in root zone (Naseby et al., 2000). It could give a great influence on roots formation and yield (Harris et al., 2000). Factors causing differences in plant response were varied, such as application techniques and seeds used. Each cultivar had different morphological characteristics. It was cause of differences in the response three cultivars in associated with Trichoderma incorporated to seed.

Trichoderma was able to associated with plant roots to improve early growth of seeds and support the further development. The results were in accordance with previous studies. As reported by Mastouri et al. (2010), tomato seed treated with Trichoderma harzianum accelerate germination and increases seed vigor. Landa et al. (2004) reported that the use of biological agents significantly improved the viability and vigor of Chickpea, compared with the untreated seed.

Trichoderma mechanism to promote plant growth was through an increase in the transfer of nutrients from soil to the roots, which were supported by the ability of Trichoderma to colonize the roots. Trichoderma was capable of infecting plant roots, and as the result would be able to promote plant growth and protect plants. Another benefit that could be given to plants, such as IAA hormone produced by Trichoderma to spur the development of plant roots (Harman, 2000). This was in line with research done by Naseby et al. (2000), which showed that Trichoderma could increase root weight and dry weight of bean plants, compared with no Trichodema.

Healthy plants with properly developed root systems associated with a high yield were reported by Harris et al. (2000). It was stated that a healthy plant with root system is well developed to survive in adverse conditions at the beginning of the growth and association 
with a high yield. The use of Trichoderma acted as biocontrol could reduce multiplication of pathogens and could be a driver of growth and plants development, improve soil fertility, produce enzymes that could degrade cell wall of fungal pathogens, produce antibiotics that could kill pathogens, and as inducers of plant resistance (Harman, 2000).

\section{CONCLUSION}

Based on these results, it could be concluded that the method of seed treatment with Trichoderma on the sandy coastal land was able to improve growth and yield of shallot. Soaked, sprayed, or integrated with matriconditioning plus rice husk charcoal or brick in combination with Trichoderma agents were effectively improve growth and yield of shallot, compared with non treated plant. The best technical treatment for Tiron cultivar was soaked in Trichoderma, and Crok was sprayed with Trichoderma, while Biru was applied with brick in combination with Trichoderma.

\section{ACKNOWLEDGEMENT}

Acknowledgement are due Australian Center for International Agricultural Research (ACIAR) for financial provided to author, appreciate to all employees in the Department of Agronomy Faculty of Agriculture Gadjah Mada University.

\section{REFERENCES}

Anonymous. 2015. Productivity Shallot By Province, 2010-2014. Yogyakarta: BPS Provinsi D. I. Y.

Harman, G. E. 2000. Myths and Dogmas of Biocontrol. Plant Dis., 84: 377-393.

Harris, D., R. S. Tripathi and A. Joshi. 2000. OnFarm Priming to Improve Crop Establishment and Yield in Direct-Seeded Rice. Paper presented to the International Workshop on DrySeede Rice Technology, Bangkok, IRRI, 25-28 January.

Ilyas, S. 2006. Seed Treatments Using Matriconditioning to Improve Vegetable Seed Quality. Bul. Agron., 34: 124-132.

Landa, B. B., J. A. Navas-Cortes, R. M. JimenezDiaz. 2004. Integrated Management of Fusarium Wilt of Chickpea with Sowing Date, Host Resistance and Biological Control. Phytopathology, 94: 946-960.

Lanzotti, V. 2006. The Analysis of Onion and Garlic. J. Cromatogr, 1112 (1-2):3-22.

Merhi, F., J. Auge, F. Rendu and B. Bauvois. 2008. Allium Compounds, Dipropyl and Dimethyl Thiosulfinates as Antiproliferative and Differ- ntiating Agents of Human Acute Myeloid Leukemia Cell Lines. Abstract Biologics. Dec, 2(4): 885-95.

Monte, E. 2001. Understanding Trichoderma:Between Biotechnology and Microbial Ecology. Int Microbiol., 4: 1-4.

Mastouri, F.; T. Bjo“"rkman and G.E. Harman. 2010. Seed Treatment with Trichoderma Harzianum Alleviates Biotic, Abiotic, and Physiological Stresses in Germinating Seeds and Seedlings. Phytopathology, 100: 1213-1221.

Naseby, D., J. Pascual and J. Lynch. 2000. Effect Of Biocontrol Strains Of Trichoderma On Plant Growth, Pythium Ultimum Populations, Soil Microbial Communities And Soil Enzyme Activities. Journal of Applied Microbiology, 88: 161-169.

Rajiman, 2014. Effect of Soil Improvement Materials In Beach Sand Land Against Soil Quality. Proceedings of the National Seminar on Suboptimal Land: 147-154.

Rajiman, Y., P. Yudono, E. Sulistyaningsih, and E. Hanudin. 2008. Effect of Soil Movement to Physical Properties of Soil and Shallot Yield on Bugel Kulon Progo District Sand Land. Agrin Journal, 12(1): 67-77.

Shoresh, M., G. E. Harman, and F. Mastouri. 2010. Induced Systemic Resistance and Plant Responses to Fungal Biocontrol Agents. Annu Rev Phytopathol., 48: 21-43.

Sulistyaningsih, E., K. Yamashita and Y. Tashiro. 2002. Haploid Induction From F1 Hybrids Between CMS Shallot whit Allium galanthum cytoplasmaand commo onion by unpollinated flower culture. Euphytica, 125: 139-144.

Sutariati, G. A. K., S. Leomo, and T. C Rakian, 2014. Performance of Growth and Results of shallot (Allium Ascalonicum L.) Bulbs In Various Sizes And Technology Leisa. Agriplus., 24(1): 12-19.

Sutariati, G. S. K. and A. Khaeruni 2013. Seed Biomatriconditioning Using Rhizobacteria for Growth Promotion and Increase the Yield of Sorghum (Sorghum bicolour (L.) Moench) on Marginal Soil. Agricultural Science Research Journals, 3(3): 85-92. 